\title{
THE CONTRIBUTIONS OF CHRIST APOSTOLIC CHURCH STUDENTS' ASSOCIATION (CACSA) TO THE GROWTH AND EXPANSION OF CHRIST APOSTOLIC CHURCH NIGERIA, 1971-2015
}

\author{
Afolabi Samuel Oluseyi Ph.D. \\ Biographical Sketch of the Author \\ AFOLABI, Samuel Oluseyi holds a Ph.D. in Religious Studies from the University of Ibadan, Nigeria. \\ $\mathrm{He}$ is a Lecturer in Church History, Church Planting and Growth at Michael Olowere College of \\ Theology (MOCOT), Ashi, Ibadan, Oyo State, Nigeria. \\ $\mathrm{He}$ is an alumnus and a lecturer of Missions and Exposure Training - MET (Pentecostal Assemblies of \\ Canada), Pretoria, South Africa. \\ He is the Senior Pastor of Christ Apostolic Church All Nations Assemblies, Ibadan, Nigeria.
}

Article DOI: https://doi.org/10.36713/epra5053

\begin{abstract}
Christ Apostolic Church was the foremost African Indigenous Church in Nigeria and its history dates back to 1918. The growth and expansion of the church in Nigeria was aided by the activities of its youth organisations, prominent among which is the Christ Apostolic Church Students'Association. This article examines the origin of the Association, its vision, administration and programmes. The article also highlights the various contributions of the society to the growth and expansion of the church via evangelism and church planting, music ministry, establishment of Campus Fellowship Centres, promotion of Christian/formal education, career development and leadership development. The study adopted Matthew Seebach's theory which is based on active forms of participation of youths in which the involvement of young people results in an impact on a process, influences a decision, or produces an outcome. ${ }^{1}$ Data were gathered through the use of structured oral interview, questionnaire, archival materials and bibliographical search.
\end{abstract}

KEYWORDS: Christ Apostolic Church, Association, Youths, Growth and Expansion.

\section{INTRODUCTION}

The period from the $19^{\text {th }}$ century to the present has been characterised by the establishment and growth of numerous indigenous Churches and prayer groups in Africa. These groups have not only taken root but they have proliferated and shown phenomenal growth particularly in Sub-Saharan Africa. ${ }^{2}$ One of the Churches in this category is the Christ Apostolic Church which started as an indigenous prayer group in 1918 and later went through many stages before it finally adopted its present name. ${ }^{3}$ The activities of the Christ Apostolic Church Student Association, among many other factors, have contributed to the growth and expansion of the church in Nigeria.

The origin, vision and spread of Christ Apostolic Church Students' Association (CACSA)

Sometime in April, 1970, at the C.A.C Bethel, Abadina, University of Ibadan, a group of undergraduate students, led by Bro. Samuel Oluwabusuyi, Arogundade, a Political Science student, was praying. During the prayer, the Lord showed Bro. Arogundade a vision in which he saw that a torrent was sweeping away the youths. He related this vision to his 
mates after the prayer session. With further prayers for authentic meaning, and encouragement from his mates, this vision was relayed to the leader of the C.A.C Bethel, Prophetess, J. O. Ogunranti who did not only pray with them but also enlightened them about the mind of God for that season. She stated that it was not only that the youths of the church are being swept away by the torrent of worldliness. God was looking for someone who would stand in the gap, who would not only pray but would act to extricate and rescue the youths from the torrent of worldliness and satanic domination. ${ }^{4}$

Prophetess Ogunranti, in the wisdom of God went to meet the then spiritual leader of the C.A.C Mission, Pastor E. T. Latunde (of blessed memory) to intimate the church authority with this vision. The authority of the Mission under the leadership of Pastor E. T. Latunde asked three of the most senior prophets in the Mission to seek the face of the Lord about the authenticity of the vision independently. Confirmation came from all of the three people, and Bro. Arogundade was given the green light to pursue the vision. ${ }^{5}$

The Association started from the University of Ibadan in 1971 and took root in other higher institutions in the country. The group adopted the motto "Christ leads, we follow". Her operations were mainly on campuses of higher institutions, targeting and reaching out to young elites of C.A.C. Among the foremost branches to be established was that of the University of Ife (now Obafemi Awolowo University, Ile-Ife). Branches of the Association were also established at the Mission's secondary schools in the South Western part of the country. In spite of the vibrancy of the Light of the World Society in the local assemblies, branches of the Association sprang up in the local assemblies as a meeting point for its Higher Institution members during holidays. ${ }^{6}$

Interest in the Association was overwhelming. Young men and women who were not necessarily undergoing any formal education came in large numbers to join the local assembly branches to study the Word of God and to pray. The momentum of the spread was so great that within the first four to five years of the Association's existence, branches had sprung up in most states of the country. ${ }^{7}$

\section{The Administration of CACSA}

The Association started with a seven-member executive committee of five officers and two ex-officio members. The first sets of officers were brothers Arogundade (President) Ayo Omideyi (Secretary), Tony Falode, Tunde Adefarakan and Sister Tosin Oni (Later Mrs. Akin Ojo, of blessed memory). The group was registered with the University of Ibadan authority in 1971. Prophetess J. O. Ogunranti was the Matron while Prof. A. M. A. Imevbore was the Patron of the Association. ${ }^{8}$

As the organisation was growing in membership and expanding, there was the need to have a larger committee to oversee its activities. Hence, by 1975/76, a National Executive Council (N.E.C) comprising the national officers (about 9 members) and all local leaders had emerged. The tenure of each NEC was three years. The last NEC was dissolved in 1997, giving room to the Directorate system with the Governing council (GC) as the highest ruling body while at the top of the hierarchy is the President.

a. The President: The president stands out as the spiritual leader of the group and the final arbiter (with counsel from Governing council) on all spiritual and administrative matters of the Association. That is, instructions (spiritual and administrative) flow out from him.

b. The Governing Council (GC): This body formulates policies as deems fit and as may be suggested by the Council of Directors (COD). The policies thus formulated are passed down to the concerned Directorate for implementation \{see fig I\}. The body also ensures compliance of all concerned with the national policy and approved guidelines. Disciplinary actions, appointments and welfare of employees are administered by the GC.

c. Council of Directors (COD): This is purely an advisory council to the GC. The council is made up of all Directors, Deputies, and Secretaries. The body makes suggestions or recommendations to the GC on policy formulation and also takes directive from GC as to the implementation of these policies.

d. Directorate Level: Each Directorate is headed by a Director but assisted by the Deputy and a Secretary. Other members of the Directorate are drawn from each state where CACSA is in operation. Each Director has a member representing him in each state. For instance, Director of Finance is represented at the state level by either the State Treasurer or Financial Secretary. The representatives of all Directors form the Executive Councils headed by the State Minister. However, information and authority flow directly to these representatives through the State Ministers.

e. State Ministers: These are the representatives of the President at the state level. They perform the functions of the President at the state level, with due delegation. Although they have direct 
access to the President, they still receive policy instructions from Directors for implementation. Their linkage with the President is purely on supervisory matters as it relates to progress and problems of assemblies and fellowship centers in the states. Assembly Ministers are to relate to the State Ministers and not the President directly.

f. State Executive Committee: This body sees to the implementation of the group's policies at the state level as may be directed by the appropriate Director through State Minister.

g. State Executive Council: This is an organ through which the State Minister administers the assemblies in the state. It is made up of all Assembly Ministers and Secretaries in the state.

h. Zonal Executive Committee: A Zone is made of two or more branches of CACSA. It is expected that there would be a replicate of offices and duties of offices at the state level. The Zonal Executive takes orders from the State Minister.

i. Local Church Council:- This is the governing body of the local assembly but chaired by the Assembly Minister. In areas where there are zonal arrangements, it takes instructions from the Zonal Executive but where this does not exist, it takes instruction from the State Executive committee.

\section{The Programmes and Activities of CACSA:}

Its programmes focused more on Scriptural teachings, seminars and specialised trainings that emphasise the spiritual development of its members. ${ }^{9}$ Some of the programmes are: Annual National Conference which held in July/August and December conference. The first National Conference took place at the defunct C.A.C Teachers' College, Efon Alaaye in July 1971 and was rotated among different states of the federation until 1999 when the national camp ground was acquired. Other programmes include monthly Mountain Top prayer retreat at Ede Mountain in Ede, Osun State; Annual "ACADA for Christ" Conference for student fellowships in higher institutions; Leadership retreats and a host of others that are meant to enhance the spiritual development of members.

\section{THE CONTRIBUTIONS OF CACSA TO CHRIST APOSTOLIC CHURCH, NIGERIA. Evangelism and Church Planting}

Christ Apostolic Church Students' Association got involved in evangelism through its monthly programme tagged "Volunteer for Christ". The programme which was purposely meant for evangelistic outreaches took members of the group out of their stations to villages and rural areas for a weekend. During the programme, the participants got involved in fervent prayers, house to house evangelism, open air crusades and tract distribution. Traveling Secretaries/Field Evangelists were appointed to oversee the effectiveness and success of the programme. Past editions of the programme were held in several locations which include Ede, Osogbo, Ilesa, Ido Osun, Obajoko-Iwo, (Osun State),Oyo, Ibadan,(Oyo State), Odo Owa, Owo, Efon Alaaye, Ifaki Ekiti, Ado Ekiti, (Ondo/Ekiti States) and Iperu, Moriwi, (Ogun State). ${ }^{10}$ The operations of this programme led to the establishment of new Assemblies of C.A.C in rural areas and this in turn led to the numerical and spiritual growth of the church. ${ }^{11}$

Apart from the monthly evangelistic outreaches which led to the establishment of new C.A.C Assemblies in rural areas, the group received a divine mandate to embark on the establishment of worship and fellowship centres during the Minna conference in 1986.The response was slow initially but, the divine order became fully effected when the C.A.C crisis came on board in $1992 .{ }^{12}$

Between 1992 and July 2013, the organisation planted 15 C.A.C Assemblies in Ekiti State, 12 in Lagos State, 7 in Ondo State, 14 in Ogun State, 17 in Osun State and 11 in Oyo State, totaling 76 Assemblies in the South Western States of Nigeria. These assemblies are now organised into Districts as approved by the C.A.C Supreme Authority. ${ }^{13}$

\section{Music Ministry}

In line with its evangelistic operations, Christ Apostolic Church Student Association (CACSA) also engaged in music ministry. The body made use of Gospel Music as a tool for evangelism. In the early 80 s, the organisation had a formidable music department headed by Bro. Tope Dada (now Pastor) and supported by the likes of Brothers Dele Ajibola, Mosaku and Ayo Adeusi. The Akure branch ventured into singing classical songs, while Lagos branch under the leadership of Bro. Mosaku, followed suit. The Akure branch waxed two music albums and appeared annually in old Ondo State highly competitive Government House Carol Service consecutively for nearly a decade. ${ }^{14}$

The outstanding effort of the music department also resulted in the establishment of a private Music School for C.A.C at Ojoyin, Ife, between 1984 and 1985.15 Till date, the department has waxed three music albums and also holds an annual Choir Summit at Osogbo. 


\section{Establishment of Campus Fellowship Centres}

Christ Apostolic Church Students' Association (CACSA) had her beginning in a higher institution of learning and precisely, the premier university in Nigeria, the University of Ibadan. The Association eventually spread to other higher institutions especially in the South Western part of Nigeria. This feat was achieved by the evangelical campaign of the members from the University of Ibadan. It was through these evangelical campaigns that the membership of the Association increased. By and large, the spread of the Association into the higher institutions became established and CACSA became one of the first set of denominational groups of Christian students in higher institutions in Nigeria.

CACSA eventually became an evangelical arm of Christ Apostolic Church in the Ivory Tower and coexisted with other Christian bodies like Christian Union (CU) and the Student Christian Movement (SCM). This unique evangelical effort has helped the church (CAC) to retain within her fold many of the elites of the church that would have otherwise left the mission for other churches or ministries.

Between 1971 and 2015, CACSA has established its presence in 29 higher institutions in the South Western part of the country with a population of about 15,000 worshippers. The statistics are as follow: Ekiti State: 2; Lagos State: 1; Ogun State: 9; Ondo: 3; Osun: 8 and Oyo: 6.

\section{Promotion of Christian and Formal Education}

Christ Apostolic Church Students' Association (CACSA) contributed to the promotion of secular/Christian education in the church. The group contributed to the educational growth of the church in the following ways. ${ }^{16}$

a. Many members of the Association functioned as Sunday school teachers thereby helping to increase the level of Scriptural knowledge in the church.

b. The body publishes a periodic Bible Study manual titled "Believers Treasure" which is used as a Bible Study guide by many C.A.C Assemblies and other denominations nationwide. It also publishes a periodic Christian magazine under the title "With One Accord".

c. The organisation runs a missionary Primary School (Children Boarding School) at Osogbo, Osun State. This is aimed at producing children with sound education and good Christian background from the grassroots. CACSA took over the administration of the school which is situated at City of Life Camp, Fadeyi Estate, Ilesa road, Osogbo in 2001. The school graduated 28 pupils between 2010 and 2013 and has a staff strength of 8 teachers as at $2013 .{ }^{17}$

d. A Secondary School (Christ International Academy) was established in 2002 by CACSA at Moriwi, via Imeko, Ogun State. The organisation was in full charge of the administration of the school from 2002 to 2009 with a total population of 55 students and 13 teachers before it handed over the school to the community in 2009. The school is now known as Community Grammar School, Moriwi.

e. Another Secondary School, (Christ Leads Secondary School) was established by the organisation in 2009 at the City of Life Camp, Fadeyi Estate, Ilesa Road, Osogbo. The school which started with 4 students in JS 1 had 45 students in JS and SS classes by 2013 and also had staff strength of 7 teachers. ${ }^{18}$

f. A Theological College (Pentecostal Bible College, PEBICO), was established in 1999 at Osogbo, Osun State with satellite campuses in Efon Alaaye, Ekiti State, Akure, Ondo State, and Lagos. The main campus is at City of Life Camp, Fadeyi Estate, Ilesa road, Osogbo. (See Plates).The college runs theological courses at certificate, diploma and degree levels and serves the purpose of producing men and women with sound biblical knowledge who will in turn be useful as clerics in the C.A.C mission and other denominations. The school is affiliated with Western Pacific University, in USA. ${ }^{19}$ As at 2013, the college has produced about 150 graduates.

\section{Leadership Development}

Christ Apostolic Church Students' Association also contributed to capacity building in the church. At the national and state levels, the group organises series of leadership seminars, workshops and ministerial training programmes which are centered on sound doctrine of the Scriptures, character formation and development of spiritual gifts. The leadership training programme also called "Train the Trainer" holds twice in a year with resource persons handling different topics on issues of leadership. Some of the past topics included: Factors Influencing Leadership inefficiency in the Contemporary church; Leadership and Discipline; Leadership and Productivity; Christ's Leadership Pattern; The Importance of Wisdom and Meekness in Leadership; and Take Charge of your 
Character. Others are: Beware of Covetousness; Dangers of Covetousness; What shall it Profit a Man?; Rich but Poor Leader; and Leaders and Modern Technology. As a result, many leaders have been developed and by this means; the Association has become a veritable recruitment ground for the mother Church. The products of the group have operated in the church as Sunday school teachers, choir members, ushers, juvenile teachers, interpreters, prayer warriors and Pastors. A great number of the members have been appointed into leadership positions and ordained as Pastors, Evangelists, Elders, Deacons and Deaconesses in the Church. ${ }^{20}$

Such leaders include Pastor Aluko C.A.C National Sunday School Coordinator (Akure), Pastor J. Ayo Owoseye, former CACSA Organising \& Publicity Secretary (Lagos), Pastor(Prof.) C. O.Oshun (Lagos), Pastor (Prof.) Akinsoyinu (Ibadan), Pastor Isaac Ijaopo (Ibadan), Pastor Segun Oloyede (Ibadan), Pastor Ayo Adeyemo (Akure), Pastor Dr. Tope Adeyemo (Ado Ekiti), Pastor Richard Adejuyigbe (Ado Ekiti), Pastor Gabriel Adeniyi (Lagos), Pastor Dele Ajibola (Lagos), Pastor Caleb Oluwadare (OAU, Ile Ife), Pastor (Prof.) Femi Adedeji (Ile Ife), Pastor Dele Akande (Oyo)and many others, too numerous to mention.

\section{Career Development}

The origin of Christ Apostolic Church Students' Association from an academic setting gave the body a great advantage in this aspect. All the foundation members of the Association were university undergraduates and subsequently the group made great incursions into higher institutions of learning especially in the South Western part of the country and had a large followership. Moreover, many members of the group still retained their membership after graduation from the university.

It is on record that in the 1980s the Association registered as an "Employer of Labour" with the National Youth Service Corps (NYSC). This made it possible for the graduating members of the Association to undertake their one-year National Service within the group and they were posted wherever the group needed them. ${ }^{21}$

The Association has produced many academic icons, males and females who have succeeded in their various chosen fields. Some of them include: Prof. Bunmi Osun (LASU), Prof. Bisi Ogunsina (UNILORIN), Prof. Akinsoyinu (U.I and Babcock University, Ilisan), Prof. Seun Adejuyigbe, Prof. Osafeyinti, Prof. Dosu Oyewole, Prof. Femi Adedeji (Present H.O.D, Music Department, OAU, Ile Ife, Osun State), Dr. Femi Awodiran (OAU, Ile Ife), Dr. Rufus Akomolafe (OAU, Ile Ife), Dr. Joshua Dada (Ile Ife),
Pastor Dr. Tope Adeyemo (Ado Ekiti), Dr. Mrs. Ojo (Ile Ife), Mrs. Funke Adebanjo (Controller of Prisons, Nigeria Prisons Service, Abuja) and a host of other Ph.D., Masters and first degree holders. ${ }^{22}$

The emergence of academicians in the church has greatly enhanced the educational enlightenment and operations of the church while it has also helped to increase the numerical strength of the church by attracting people of like minds to join the fold.

\section{CONCLUSION}

Youths must not only be seen as leaders of tomorrow but leaders today. Young people are the church of today. We cannot afford to let them wait until they are older to make important contributions to the life of the church. Their ministry is essential. The things they can do, the places they can go and the impacts they can make are enormous. Their ministry builds the church, reaches the lost, and enhances the continuity of the church. We need them now just as the early church needed them. Since they are physically, emotionally and intellectually ready to respond in certain ways, more than adults, they have a freshness of approach, idealism, creativity and boundless energy. Their capacities which in the past have been vastly underestimated should be recognised and utilised to the full. 23

\section{ENDNOTES}

${ }^{1}$ Matthew Seebach, (2008) "Youth Participation and Youth Work: A Conceptual Review" Journal of Youth Work Ireland, Vol.3 No 2,: accessed Feb. 1,2020, https://www.youthworkireland.ie/images/uploads/gener al/YWI Journal_Vol3No2 03 Youth_Participation.pdf

2 Deji Ayegboyin, and Ademola Ishola, African Indigenous Churches, (Lagos: Greater Heights Publications, 1997), 10.

3 Babs Mala, "Christ Apostolic Church: Its Present Pre-occupation", in African Independent Churches in the $80 \mathrm{~s}$, ed. Babs Mala (Lagos: Organisation of African Instituted Churches, 1983), 67.

4 The Directorate of Publicity and Publication, CACSA, Christ Apostolic Church Students' Association: The vision and mission in thorns. (Akure, The Directorate of Publicity and Publication, CACSA, 2005) 1 .

5 Ibid.

6 Feyi Omolola, A General in God's Army: A Biography of Samuel Oluwabusuyi Arijesudade. (Osogbo, The Directorate of Publicity and Publication, CACSA 2010), 45-53.

${ }^{7}$ Ibid. 
8 The Directorate of Publicity and Publication, CACSA, Christ Apostolic Church Students' Association: The vision and mission in thorns. (Akure, The Directorate of Publicity and Publication, CACSA, 2005), 2,6.

9 Adeware Alokan, The Christ Apostolic Church (Nigeria: Ibukunolu Printers Ltd., 1991), 267273.

10 Tope Adeyemo (Pastor), CACSA General Secretary. Interview Respondent. Interviewed on 23/05/14 at CACSA National Camp Ground, City of Life, Osogbo.

11 Ibid.

12 The Directorate of Publicity and Publication,

CACSA, Christ Apostolic Church Students'

Association: The vision and mission in thorns. (Akure, The Directorate of Publicity and Publication, CACSA, 2005), 5-6.

13 Tope Adeyemo (Pastor), CACSA General Secretary. Interview Respondent. Interviewed on 23/05/14 at CACSA National Camp Ground, City of Life, Osogbo.

14 Richard Adejuyigbe, The Early Years of C.A.C Students' Association (1970-1992)". In The Stewardship of Pastor Olu Arijesudade. (Lagos: Pesther Brands Ltd., 2014) 9.

15 Femi Adedeji (Prof).H.O.D Music Department, OAU, Ife.Interview Respondent. Interviewed on $16 / 05 / 14$ at his church site, Truth of the Gospel Ministries, Ife.

16 The Directorate of Publicity and Publication, CACSA, Christ Apostolic Church Students' Association: The vision and mission in thorns. (Akure, The Directorate of Publicity and Publication, CACSA, 2005), 41-42.

17 Noah Akintemi (Pastor), Administrator, Children Boarding School and Christ Leads Secondary School, Osogbo. Interview Respondent. Interviewed on 23/05/14 at CACSA National Camp Ground, City of Life, Osogbo.

18 Ibid.

19 The Directorate of Publicity and Publication, CACSA, Christ Apostolic Church Students' Association: The vision and mission in thorns. (Akure, The Directorate of Publicity and Publication, CACSA, 2005), 41-42.

20 Tope Adeyemo (Pastor), CACSA General Secretary. Interview Respondent. Interviewed on 23/05/14 at CACSA National Camp Ground, City of Life, Osogbo.

21 Ayo Owoseye, "CACSA and the Man, Pastor Samuel Olubusuyi Arijesudade". In The
Stewardship of Pastor Olu Arijesudade. (Lagos: Pesther Brands Ltd., 2014), 15.

22 Femi Adedeji (Prof).H.O.D Music Department, OAU, Ife.Interview Respondent. Interviewed on 16/05/14 at his church site, Truth of the Gospel Ministries, Ife;

See also, Femi Adedeji, Biblical Christian Leadership: In Honour of Samuel Olubusuyi Arijesudade. (Ile Ife, The Truth Publishers, 2014), 1-247.

23 O. Ademola. "The Youths in Nation Building: A Case Study of Nigerian Baptist Convention Youth Organisations" (M.A Diss, University of Ibadan. 1994), 5. 